\title{
PERAN KELOMPOK SOSIAL ARGOWAYANG DALAM MENANAMKAN NILAI KESADARAN LINGKUNGAN
}

\author{
Seka Andriani, M. Syahri, M. Mansur \\ FKIP Universitas Muhammadiyah Malang, Indonesia \\ Email: Seka.andriani@gmail.com
}

\begin{abstract}
ABSTRAK
Kelompok sosial Argowayang merupakan kelompok sosial yang bergerak dalam bidang lingkungan hidup. Tujuan dari penelitian adalah 1) upaya yang dilakukan oleh kelompok sosial Argowayang terhadap penanaman nilai kesadaran terhadap lingkungan hidup, 2) faktor pendukung dan faktor penghambat, 3) solusi untuk mengatasi faktor penghambat. Metode yang digunakan kualitaif deskriptif. Sumber data yang digunakan adalah Kepala Desa Galengdowo, ketua dan anggota Kelompok sosial Argowayang, dan masyarakat Desa Galengdowo. Tempat penelitian yakni di Desa Galengdowo. Hasil penelitian dikemukakan bahwa 1) upaya yang dilakukan bersama masyarakat dan anak-anak, 2) faktor pendukung yang diterima berupa kerjasama yang kompak antar anggota dan dukungan dari lembaga lain sedangkan faktor penghambat yang dialami berupa kesadaran masyarakat dan faktor cuaca, 3) solusi untuk menangani faktor penghambat berupa diadakan penambahan anggota kembali, dan diadakan sosialisasi kepada masyarakat.
\end{abstract}

Kata Kunci : Kelompok sosial Argowayang; Nilai Kesadaran; Lingkungan hidup

\begin{abstract}
Argowayang's social group is a group that is engaged in the field of the environment. The purpose of the research about 1) the efforts thatis done by the social group of Argowayang toward the cultivation of thevalueof awareness against the environment, 2) supporting factors and inhibiting factors, 3 ) solution ror the resolve inhibiting factors. Research methods that used in this research is qualitative research design. Data source that used is headman Galengdowo village, chairman and member Argowayang's social group, and society Galengdowo village. Place research in the Galengdowo village. The results of the study showed that 1) there are two kinds of efforts which are done by Argowayang's social group in instilling the value of environmental awareness in the Galengdowovillage; namely the society and students. The society activities are biogas manufacture and reforestation, while the kids doing educational tours, 2) factor endowments that are accepted in the form of solid cooperation between members and other agencies that provide support in the form of directives, guidance or energy restricting factors arethe lack of public awareness of the environment and the weather, 3 ) the solution to overcome the restricted factors are to be held back the addition of group's members, and held the socialization to society.
\end{abstract}

Keywords: Agrowayang social groups; Instilling the Values; Environment

\section{PENDAHULUAN}

Kehidupan tidak dapat dipisahkan dari lingkungan. Karena lingkungan merupakan tempat berlangsungnya sebuah kehidupan. Mulai dari kehidupan pada tingkat terkecil atau sel sampai yang paling kompleks pada tingkat biosfer. Menurut Prasetyo, Ketut dan Hariyanto (2017:52) definisi lingkungan hidup adalah kesatuan ruang dengan semua benda, daya, keadaan, dan makhluk hidup, termasuk manusia dan perilakunya yang mempengaruhi kehidupan dan kesejahteraan manusia serta makhluk hidup lainnya. Baik atau buruknya kelangsungan sebuah kehidupan tergantung bagaimana lingkungan tersebut sebagai faktor pendukung kehidupan tersebut.

Upaya untuk membangkitkan kesadaran warga negara terhadap lingkungan bukan perkara yang mudah, seperti halnya mengajarkan bagaimana 
cara membuang sampang pada tempatnya. Pelajaran penting yang harus diterapkan yakni bagaimana membiasakan warga negara untuk tetap membuang sampah pada tempatnya. Mengingat banyaknya masyarakat yang sudah terbiasa dengan kebiasaan yang kurang baik, contohnya membuang sampah di sungai. Hal ini jika terus dilakukan akan menyebabkan banjir.

Kondisi sungai dengan kualitas air yang kurang layak tersebut seperti ada di Desa Galengdowo yang terletak di Kecamatan Wonosalam Kabupaten Jombang. Tingkat kesadaran masyarakat tentang menjaga kebersihan lingkungan masih kurang. Hal ini dapat dilihat dari masih banyaknya sampah yang berada di sungai. Sebagian besar masyarakat masih membuang sampah rumah tangga ke sungai daripada membuang sampah ke tempat yang telah disediakan. Persoalan yang terjadi tidak hanya sampah rumah tangga saja yang dibuang ke sungai, melainkan kotoran hewan ternak juga dibuang ke sungai. Hal ini berakibat mencemari kualitas air sungai yang ada disekitar, sehingga air sungai bau dan tidak dapat digunakan.

Mengacu pada UU No. 32 Tahun 2009 tentang Pengelolaan lingkungan hidup menyebutkan bahwa masyarakat memiliki hak dan kewajiban terhadap lingkungan hidup yang mereka tempati. Hak warga negara tentang lingkungan hidup termuat dalam pasal 66 UU No. 32 Tahun 2009 tentang Pengelolaan Lingkungan Hidup yang berbunyi "Setiap orang yang memperjuangkan hak atas lingkungan hidup yang baik dan sehat tidak dapat dituntut secara pidana maupun digugat secara perdata". Sedangkan kewajiban warga negara terhadap lingkungan hidup tercantum dalam pasal 67 UU No. 32 Tahun 2009 tentang Pengelolaan Lingkungan Hidup yang berbunyi "Setiap orang berkewajiban memelihara kelestarian fungsi lingkungan hidup serta mengendalikan pencemaran dan atau kerusakan lingkungan hidup".

Berdasarkan hak dan kewajiban warga negara munculnya berbagai kelompok sosial atau komunitas dalam bidang lingkungan menandai bahwa kesadaran terhadap lingkungan hidup mulai tumbuh ditengahtengah masyarakat. Berdasarkan hasil observasi munculah sebuah kelompok sosial yang berada di Kecamatan Wonosalam yang berdiri dengan memiliki latar belakang lingkungan. Kelompok sosial tersebut diberi nama Argowayang, yang terletak di Desa Galengdowo Kecamatan Wonosalam Kabupaten Jombang.

Purwasih dkk (2018:48) mengemukakan pengertian kelompok sosial adalah kumpulan individu yang memiliki kesadaran bersama akan keanggotaannya dan saling berinteraksi. Tiap-tiap anggota kelompok sosial saling memperhatikandanberhubungansatu samalain. Kegiatan yang dibuat oleh Kelompok sosial Argowayang tidak hanya ditujukan bagi masyarakat Desa Galengdowo saja, melainkan juga bagi anak-anak sekolah. Kelompok sosial Argowayang mempromosikan kegiatan yang mereka lakukan atau biasanya disebut wisata edukasi di media sosial Facebook.

Kegiatan yang dilakukan oleh kelompok sosial Argowayang termasuk kegiatan pembelajaran yang dilakukan di luar sekolah. Pendidikan luar sekolah sebagai salah satu institusi yang memang dibuatolehpemerintahuntukpemberdayaan masyarakat, harus mampu membuat program pemberdayaan masyarakat secara professional dan bertanggungjawab. Pendidikan luar sekolah ikut berperan dalam pengembangan sumberdaya manusia di negeri ini (Syamsi, 2010:66).

\section{METODE}

Penelitian ini menggunakan pendekatankualitatifkarenamemilikitujuan mendeskripsikan upaya yang dilakukan oleh kelompok sosial Argowayang dalam menanamkan nilai kesadaran terhadap lingkungan hidup di Desa Galengdowo 
Kecamatan Wonosalam Kabupaten Jombang, faktor pendukung dan faktor penghambat yang dialami oleh kelompok sosial Argowayang dalam menanamkan nilai kesadaran terhadap lingkungan hidup di Desa Galengdowo Kecamatan Wonosalam Kabupaten Jombang, serta solusi dalam mengatasi faktor penghambat yang dialami oleh Kelompok sosial Argowayang.

Pendekatan kualitatif ialah pendekatan yang di dalam usulan penelitian, proses, hipotesis, turun ke lapangan, analisis data dan kesimpulan data sampai dengan penulisannya mempergunakan aspek-aspek kecenderungan, non perhitungan numerik, situasional deskriptif, interview mendalam, analisis isi, bola salju dan story (Musianto, 2002:125). Penelitian ini dilakukan di Desa Galengdowo Kecamatan Wonosalam Kabupaten Jombang karena sumber data yang digunakan adalah 1) Kepala Desa Galengdowo, (2) Ketua Kelompok Sosial Argowayang, (3) Anggota, (4) Masyarakat Desa Galengdowo.

Penelitian ini dilaksanakan selama 2 bulan pada bulan Oktober sampai Desember 2018. Prosedur penelitian meliputi tahap pra lapangan, tahap pelaksanaan penelitian, dan tahap akhir penelitian. Teknik pengumpulan data yang digunakan adalah observasi, wawancara dan dokumentasi. Analisis data dalam penelitian kualitatif dapat dilakukan sejak sebelum memasuki lapangan, selama di lapangan, dan setelah selesai di lapangan (Sugiyono, 2016:89). Model analisis interkatif Miles dan Huberman ada 3 langkah : 1) Reduksi data, 2) Penyajian data, 3) Verifikasi dan Penarikan Kesimpulan. Temuan data dalam penelitian kualitatif dinyatakan valid apabila tidak ada perbedaan antara yang dilaporkan peneliti dengan apa yang terjadi sesungguhnya yang ada di lapangan (Sugiyono, 2016:119). Pengujian keabsahan data dalam penelitian kali ini menggunakan triangulasi data.

\section{HASIL DAN PEMBAHASAN}

Kelompok sosial Argowayang adalah sebuah kelompok sosial yang terletak di Desa Galengdowo Kecamatan Wonosalam Kabupaten Jombang. Kelompok sosial atau social group adalah himpunan atau kesatuan manusia yang hidup bersama, karena adanya hubungan di antara anggota kelompok. Hubungan tersebut antara lain menyangkut hubungan timbal balik yang saling memengaruhi dan juga suatu kesadaran untuk saling menolong (Soekanto, Soerjono dan Budi Sulistyowati, 2013:104).

Soegianto (2010:1) mengemukakan lingkungan adalah seluruh faktor luar yang memengaruhi suatu organisme; faktorfaktor ini dapat berupa organisme hidup (biotic factor) atau variabel-variabel yang tidak hidup (abiotic factor). Dari hal inilah kemudian terdapat dua komponen utama lingkungan, yaitu: a) Biotik: Makhluk (organisme) hidup; dan b) Abiotik: Energi, bahan kimia, dan lain-lain.

Kelompok sosial Argowayang merupakan satu-satunya kelompok yang berdiri dibawah naungan BUM Desa Loh Jinawi Desa Galengdowo dan satu-satunya yang ada di Kabupaten Jombang. Latar belakang awal terbentuknya kelompok sosial Argowayang adalah dibentuknya pokdarwis. Pokdarwis adalah kelompok sadar wisata, pokdarwis ini bertugas untuk mengelola potensi wisata yang ada di Desa Galengdowo. Kelompok sosial Argowayang berdiri pada awal tahun 2015.

\section{Upaya yang Dilakukan Kelompok Sosial Argowayang dalam Menanamkan Nilai Kesadaran Terhadap Lingkungan Hidup}

Berdasarkan UU No. 32 Tahun 2009 tentang pengelolaan lingkungan hidup, kita sebagaimanusiadankhususnyawarganegara Indonesia harus memberikan tanggung jawab terhadap lingkungan. Menjaga dan merawat lingkungan agar senantiasa tetap terjaga dan sumber daya yang terdapat 
di lingkungan dapat dinikmati oleh anak cucu kita kelak. Awal mula kelompok Argowayang adalah berupa kelompok sadar wisata. Seiring dengan berkembangnya masalah-masalah yang ada di lingkungan sekitar, maka kelompok Argowayang juga ikut berpartisipasi terhadap lingkungan yang ada di Desa Galengdowo.

Kelompok sosial Argowayang melakukan kegiatannya dibantu oleh pemerintah Desa Galengdowo. Bentuk kegiatan yang dilakukan oleh kelompok sosial Argowayang berupa wisata edukasi yang dilaksanakan bersama anak-anak sekolah dan kegiatan yang dilaksanakan bersama dengan masyarakat. Kegiatan yang dilakukan oleh Kelompok sosial Argowayang sebanyak 2 kali dalam satu bulan. Wisata edukasi ini dilakukan oleh kelompok sosial Argowayang dengan sasaran anak-anak yang masih duduk dibangku sekolah. Temuan yang diperoleh dari penelitian ini bahwa kegiatan yang dibuat oleh Kelompok sosial Argowayang terdapat dua macam. Kegiatan bersama masyarakat dan anak-anak sekolah.

Kegiatan yang dilakukan dengan masyarakat berupa pembuatan biogas, penanaman pohon di sekitar aliran sungai, dan kerja bakti. Pembutan biogas ini adalah salah satu upaya untuk mengurangi limbah yang dibuang ke sungai. Sebelum ada progam pembuatan biogas, limbah kotoran hewan ternak dibuang ke sungai. Hal ini menyebabkan tercemarnya air sungai yang ada disekitar. Pemerintah Desa Galengdowo membuat program pembuatan biogas dibantu oleh Universitas Ciputra. Masyarakat mendapatkan subsidi dana dalam pembuatan biogas. Selain mengurangilimbah, hal ini juga mengurangi penggunaan elpigi. Selanjutnya kegiatan yang dilakukan berupa penanaman pohon disekitar aliran sungai. Hal ini dilakukan karena Desa Galengdowo yang rawan terjadinya tanah longsor dan banjir bandang.
Kegiatan selanjutnya yang dilakukan bersama anak-anak sekolah berupa wisata edukasi. Wisata wdukasi yang dilakukan berupa berkunjung ke peternakan sapi perah milik warga Desa Galengdowo, berkunjung ke perkebunan salak, dan berwisata ke Grojokan Kali Sat. Di samping berwisata, anak-anak juga diberikan edukasi mengenaiperawatan sapi perah, cara memanen buah salak, sampai budidaya buah salak. Kegiatan terakhir yang dilakukan dalam wisata edukasi berupa berkunjung ke Grojokan Kali Sat. Sepanjang perjalan, anak-anak akan diperkenalkan dengan keanekaragaman hayati yang ada disekitar.

Tujuan kelompok sosial Argowayang ingin menumbukan kesadaran terhadap lingkungan hidup adalah ingin membuat masyarakat peduli terhadap lingkungan. Karena lingkungan adalah hal terpenting bagi kehidupan manusia. Sebagai imbalan terhadap apa yang telah diberikan oleh lingkungan, maka mereka memberikan kontribusi terhadap lingkungan berupa menjaga dan melestarikan lingkungan. Pendidikan Lingkungan diharapkan mampu menjembatani dan mendidik manusia agar berperilaku bijak. Masa anak-anak merupakan perjalanan yang kritis sebagai generasi bangsa di masa mendatang. Oleh sebab itu diperlukan penanaman pengetahuan yang benar, sehingga akan dapat dijadikan bekal pengetahuan, pembentukan perilaku serta sikap positif yang tertanam dalam dirinya hingga kelak menginjak ke masa remaja dan dewasa (Mulyana, 2009:179)

\section{Faktor Pendukung dan Faktor Penghambat Kelompok Sosial Argowayang dalam Menanamkan Nilai Kesadaran Terhadap Lingkungan Hidup.}

Faktor pendukung yang didapatkan oleh kelompok sosial Argowayang adalah kerjasama yang terjalin antar anggotanya. Kerjasama yang kompak ini diperoleh dari anggota yang memiliki visi misi yang sama ingin mewujudkan Desa 
Galengdowo menjadi lebih baik. Semakin kuat kelompok, kekompakan juga semakin tinggi. Hubungan antara anggota yang pasti tinggi. Kekompakan adalah salah satu dari perilaku dan membentuk kinerja tim. Kekompakan didefinisikan sebagai sejauh mana anggota kelompok bersedia untuk bekerja sama. Ini adalah rasa kebersamaan kelompok (Irwanti, Marlinda dan Dedy Muharman, 2019:259).

Meskipun dengan adanya perbedaaan latar belakang anggota, tidak menjadikan penghambat bagi kelompok sosial Argowayang dalam melaksanakan kegiatan. Kelompok sosial Argowayang termasuk dalam pengklasifikasian kelompok formal. Waluya (2009:94) mendefinisikan kelompok formal adalah kelompokkelompok yang mempunyai peraturan yang tegas dan sengaja diciptakan oleh anggotaanggotanya untuk mengantur hubungan antara anggota-anggotanya. Hal ini terlihat dari dengan adnya pembagian tugas dan struktur organisasi dalam kelompok sosial Argowayang.

Kerjasama yang terjalin antara anggota membuat eksistensi kelompok sosial Argowayang semakin terdepan. Terbukti dengan diberikannya SK oleh Dinas Pariwisata Kabupaten Jombang sebagai kelompok yang berada dibawah naungan BUM Desa. Sebuah prestasi yang didapatkan oleh kelompok sosial Argowayang yang dijadikan motivasi untuk menjadi semakin maju. Selain faktor tersebut, ada beberapa faktor lain yang ikut melancarkan kegiatan yang dilakukan oleh kelompok sosial Argowayang. Faktor tersebut berasal dari masyarakat Desa Galengdowo, pemerintah Desa Galengdowo, Universitas Ciptra, dan Dinas Kabupaten Jombang. Bentuk dukungan dari masyarakat berupa tenaga.

Masyarakat Desa Galengdowo ikut membantu dalam kegiatan yang dilaksanakan oleh kelompok sosial Argowayang. Selain itu masyarakat juga menyediakan tempat bagi kelompok sosial Argowayang ketika melakukan wisata edukasi. Menyediakan peternakan sapi dan perkebunan salak. Antusias dari masyarakat yang tinggi, sehingga kegiatan yang dilakukan oleh kelompok sosial Argowayang beserta anak-anak sekolah atau masyarakat Desa Galengdowo dapat berjalan dengan lancar. Pendidikan lingkungan merupakan salah satu faktor penting untuk meminimalisasi kerusakan lingkungan hidup. Pendidikan lingkungan dilakukan sebagai upaya untuk meningkatkan pemahaman dan kepedulian masyarakat dalam mencari pemecahan dan pencegahan timbulnya masalah lingkungan (Adam, 2014:166).

Faktor yang tidak kalah pentingnya dari kegiatan yang dilakukan oleh kelompok sosial Argowayang yaitu dari pemerintah Desa Galengdowo. Pemerintah Desa Galengdowo menberikan dukungan dan bimbingan kepada semua anggota kelompok sosial Argowayang sehingga program-program yang telah disusun dapat berjalan dengan lancar. Karena jika tidak ada ijin yang diberikan oleh peemrintah Desa Galengdowo maka kelompok sosial Argowayang ini juga tidak akan berdiri. Selaknjutnya dukungan yang diperoleh oleh kelompok sosial Argowayang adalah dari Universitas Ciputra. Bentuk dukungan yang diberikan berupa pengetahuan tentang pembuatan biogas dan pohon-pohon dalam rangka penghijauan.

Terakhir, dukungan yang diperoleh oleh kelompok sosial Argowayang adalah dari Dinas Pariwisata Kabupaten Jombang. Diadakan kegiatan Sapta Pesona oleh Dinas Kabupaten Jombangyang diikuti oleh semua masyarakat Desa Galengdowo beserta kelompok sosial Argowayang. Kegiatan Sapta Pesona merupakan kegiatan dimana diberikan konsep sadar wisata yang terkait dengan dukungan dan peran masyarakat sebagi tuan rumah dalam upaya menciptakan lingkungan suasana 
kondusif yang mampu mendorong berkembangnya industri pariwisata. Kegiatan ini diselenggarakan pada Tahun 2018. Kegiatan ini dilakukan pertama kali oleh Dinas Pariwisata Kabupaten Jombang dan Desa Gaelngdowo adalah satu-satunya Desa yang mendapatkan program kegaiatan ini.

Selanjutnya tidak hanya faktor pendukung saja yang bepengaruh terhadap kegiatan yang diselenggarakan oleh kelompok sosial Argowayang. Faktor penghambat juga ikut mewarnai kegiatan yang diselenggarakan oleh kelompok sosial Argowayang. Faktor penghambat yang ditemukan selama proses kegiatan yang dilakukan berupa latar belakang pekerjaan yang dimiliki oleh anggota kelompok sosial Argowayang. Dengan beragamnya kegiatan yang dimiliki oleh masingmasing anggota kelompok menyebabkan kekurangan personel ketika melakukan kegiatan wsiata edukasi. Satu orang anggota bisa mengawasi sampai 15 anak. Menurut penuturan dari anggota kelompok sosial Argowayang, hal tersebut tidak mudah. Apalagi murid yang melakukan kegiatan wisata edukasi adalah anakanak SD. Mereka sering kesulitan, karena nak-anak sering berbicara sendiri dengan temannya dan tidak mau mendengarkan materi yang disampaikan.

Faktor lain yang dialami oleh kelompok sosial Argowayang adalah kesadaran masyarakat yang masih minim. Sehingga anggota dari kelompok ini sendiri tidak terlalu banyak. Sehingga dengan anggota yang minim memberikan pengaruh yang cukup berarti bagi kegiatan mereka. Selain itu dalam menjalankan kegaiatan bersama masyarakat, kendala yang dialami juga berupa tentang kesadaran msayarakat. Ketika melakukan kegiatan seperti kerja bakti atau penghijauan, masyarakat lebih memilih untuk melakukan kegiatan yang lain. Sehingga partisipasi masyarakat juga kurang.
Faktor penghambat yang terakhir adalah faktor cuaca. Kondisi cuaca tidak bisa diprediksi. Kadang panas kadang hujan, hal ini juga berpengaruh terhadap kegiatan yang dilakukan oleh kelmpok sosial Argowayang. Karena kegiatan yang dilakukan adalah kegiatan yang diluar ruangan. Sehingga dengan keadaan yang tidak mendukung, menyita waktu bagi kelangsungan kegiatan yang dilakukan oleh kelompok sosial Argowayang.

\section{Solusi Untuk Mengatasi Faktor Penghambat}

Berdasarkan faktor penghambat yang didapat oleh kelompok sosial Argowayang, maka solusi yang ditujukan untuk mengatasi faktor penghambat tersebut berupa lebih banyak melakukan sosialisasi kepada masyarakat bahwa menjaga lingkungan itu penting sekali. Bertambahnya kesadaran masyarakat otomatis akan berpengaruh terhadap jumlah anggota kelompok sosial Argowayang. Jumlah penambahan anggota baru maka menguragi beban dari anggota ketika melakukan kegiatan. Baik kegiatan bersama masyarakat maupun wisata edukasi. Kelompok sosial Argowayang merupakan kelompok yang berdiri atas dasar pandangan yang sama diantara masyarakat. Waluya (2009:89) mengelompokkan manusia didasarkan melalui hasil pengalaman praktis, intelektual, dan emosonal. Penjelasannya sebagai berikut :

1. Pengalaman praktis adalah kelompok yang didasarkan oleh aktivitas yang dilakukan oleh manusia guna memenuhi hasrat dan keinginnanya.

2. Pengalaman intelektual adalah kelompok yang didasarkan pada keterbatasan akal yang dimiliki sehingga memerlukan arahan orang lain.

3. Pengalaman emosional adalah kelompok yang didasarkan keinginan manusia untuk bersatu dengan yang lain. 
Berdasarkan pengelompokan tersebut, Kelompok sosial Argowayang memiliki kriteria pengelompokan manusia yang telah disebutkan. Manusia sebagai makhluk sosial yang tidak dapat hidup sendiri dan selalu bergantung pada lingkungannya. Kelangsungan kegiatan yang dibuat oleh Kelompok sosial Argowayang didukung oleh faktor dari dalam maupun dari luar. Kegiatan akan berjalan dengan lancar ketika semua lapisan saling bekerja sama. Kuantitas anggota kelompok dan kerja sama yang terjalin akan mempermudah kegiatan yang dilakukan, baik kegiatan bersama masyarakat atau ketika melakukan wisata edukasi. Kegiatan evasluasi juga dilakukan setelah melaksanakan kegiatan wisata edukasi atau kegiatan bersama masyarakat. Tujuan diadakan evaluasi adalah membahas kegiatan yang telah dilaksanakan, jika menemukan hambatan-hambatan agar cepat terselesaiakan.

Solusi terbaru untuk kelompok sosial Argowayang yang berkaitan dengan kurangnya anggota, akan dibantu oleh Karang Taruna dari Desa Galengdowo. Hal ini sesuai dengan hasil rapat yang dilakukan oleh karang taruna bersama aparat pemerintah Desa Galengdowo. Dengan adanya bantuan yang akan diberikan oleh karang taruna akan semakin mudah dalam melaksanakan program-program kegiatan yang tekah dibuat, sehingga tugas-tugas yang dibebankan kepada kelompok sosial Argowayang dapat ditanggung bersama dengan Karang Taruna Desa Galengdowo. Solusi terakhir untuk mengatasi kondisi cuaca yang sering mempengaruhi kegiatan yang dilaksanakan oleh kelompok sosial Argowayang adalah berupa kegiatan yang dilaksanakan sementara diberhentikan terlebih dahulu, sampai cuaca kembali normal. Mengingat letak Desa Galengdowo yang di lereng pegunungan sehingga sering terjadinya longsor. Sehimgga tidak memukingkan jika kegiatan tersebut terus dilakukan karena sangat membahayakan.

\section{SIMPULAN}

Upaya yang dilakukan oleh kelompok sosial Argowayang dalam menanamkan nilai kesadaran terhadap lingkungan hidup dilakukan dengan dua macam, dilakukan bersama masyarakat dan anak-anak sekolah. Bentuk kegiatan yang dilakukan bersama masyarakat berupa pembuatan biogas dan penghijauan. Sedangkan dengan anak-anak berupa wisata edukasi. Tujuan diadakan wisata edukasi bersama anak-anak selain memberikan gambaran tentang mata pencaharian masyarakat Desa Galengdowo juga pengenalan terhadap lingkungan hidup.

Faktor pendukung yang didapatkan oleh kelompok sosial Argowayang berupa kerja sama anggota yang solid. Faktor pendukung juga didapatkan dari oleh kelompok sosial Argowayang darimasyarakatberupakerjasama, pemerintah Desa Galengdowo yang berupa dana dan dukungan. Faktor pendukung dari luar juga diperleh dari Universitas Ciputra, dan Dinas Pariwisata Kabupaten Jombang. Sedangkan faktor penghambat yang ditemukan oleh kelompok sosial Argowayang berupa kesadaran masyarakat yang masih minim.

Kegiatan yang dilakukan, jumlah partisipasi masyarakat masih sedikit, sehingga hal ini juga berdampak pada jumlah anggota yang ada di kelompok sosial Argowayang. Faktor penghambat terakhir yang mempengaruhi kegiatan yang dilakukan oleh kelompok sosial Argowayang adalah cuaca disekitar yang tidak menentu. Kondisi cuaca yang tidak menentu, menyebabkan kegiatan yang dilakukan terganggu dan terpaksa dihentikan. Karena dengan letak Desa Galengdowo yang berada di lereng pegunungan yang rawan longsor, maka sebaiknya menghindari kegiatan yang dilakukan di daerah rawan longsor.

Solusi untuk mengatasi faktor penghambatyang ditemukanolehkelompok sosial Argowayang berupa penambahan anggota. Penambahan anggota ini dilakukan 
dengan cara melakukan sosialisasi kepada masyarakat. Penambahan anggota akan memberikan dampak bagi kegiatankegiatan yang akan dilakukan seterusnya. Jumlah anggota semakin banyak maka tugas yang didapatkan juga semakin ringan. Sedangkan solusi untuk cuaca yang tidak menentu, kegiatan yang dilakukan dihentikan terlebih dahulu hingga cuaca kembali normal.

\section{DAFTAR PUSTAKA}

Adam, Budi. 2014. Analisis Implementasi Kebijakan Kurikulum Berbasis Lingkungan Hidup Pada Program Adiwiyata Mandiri di SDN Dinoyo 2 Malang. Jurnal Kebijakan dan Pengembangan Pendidikan. 2 (2). (Online) http://ejournal.umm.ac.id diakses tanggal 20 Mei 2019.

Irwanti, Marlinda \& Dedy Muharman. 2015. Perspektif Baru Groupthink : Perbedaan Tingkat Pendidikan dalam Pengambilan Keputusan Kelompok. Jurnal Sosial dan Pembangunan. 31 (1). (Online) ejournal.unisba.ac.id diakses taggal 20 Mei 2019.

Mulyana, Rachmat. 2009. Penamaman Etika Lingkungan Melalui Sekolah Peduli dan Bebudaya Lingkungan. Jurnal Tabularasa, 6 (2). (Online) http://digilib.unimed.ac.id/712/, diakses tanggal 20 Mei 2019.

Musianto, Lukas S. 2002. Perbedaan Pendekatan Kuantitatif Dengan Pendekatan Kualitatif Dalam Metode Penelitian. Jurnal Manajemen dan Kewirausahaan, 4 (2). (Online) http://garuda.ristekdikti.go.id diakses tanggal 20 Mei 2019.
Prasetyo, Ketut dan Hariyanto. 2017. Pendidikan Lingkungan Hidup. Bandung : Remaja Rosdakarya.

Purwasih, dkk. 2018. Ensiklopedia Sosiologi. Klaten: Cempaka Putih.

Soegianto, Agoes. 2010. Ilmu Lingkungan, Sarana Menuju Masyarakat Berkelanjutan. Surabaya: Airlangga University Press.

Soekanto, Soerjono \& Budi Sulistyowati. 2013. Sosiologi Suatu Pengantar (Edisi Revisi). Jakarta: Rajawali Pers.

Sugiyono. 2016. Memahami Penelitian Kualitatif (Cetakan 12). Bandung: Alfabeta.

Syamsi, Ibnu. 2010. Pendidikan Luar Sekolah Sebagai Pemberdaya Dalam Masyarakat. Jurnal Pendidikan Luar Sekolah, 4 (1). (Online) https:// journal.uny.ac.id diakses tanggal 20 Mei 2019.

Undang-undang RI No. 32 Tahun 2009 tentang Perlindungan dan Pengelolaan Lingkungan Hidup, (Online), (http;//www.menlhk.go.id) , diakses tanggal 26 Februari 2018.

Waluya, B. 2009. Sosiologi 2: Menyelami Fenomena Sosial di Masyarakat. Jakarta: PusatPerbukuan Departemen Pendidikan Nasional. 